\title{
Using Statistical Software in Analyzing Educational Data: A Community Service to Mathematics Teacher's in 50 Kota Regency
}

\author{
Nonong Amalita ${ }^{\# 1}$, Yenni Kurniawati ${ }^{1}$, Dina Fitria ${ }^{1}$ \\ ${ }^{1}$ Jurusan Matematika Fakultas Matematika dan Ilmu Pengetahuan Alam Universitas Negeri Padang \\ Jln Prof Dr Hamka Air Tawar Padang, West Sumatera, Indonesia \\ \#Correspondence: nong mat@fmipa.unp.ac.id Tel.: +62-812-6636-820
}

Diterima 12 Novmber 2018, Disetujui 12 November 2018, Dipublikasikan 30 November 2018

\begin{abstract}
Analyzing data using statistical software is an interesting work. Many teachers in 50 Kota regency lack of it. Given a workshop on data analysis using statistical software. There is increasing ability of teachers in analyzing data using simple statistical software. They are able to organize their data on education, i.e result of exam.
\end{abstract}

Keywords —educational data, statistics, statistical software

\section{Pendahuluan}

Mengolah data menggunakan perangkat lunak statistika tidak dapat dikatakan sepenuhnya adalah hal baru bagi guru matematika SMP di Kabupaten 50 kota. Namun praktek mengolah data menggunakan perangkat lunak statistika adalah hal yang jarang dilakukan guru. Mereka baru memanfaatkannya sebatas operasi-operasi sederhana Microsoft excel. Mereka bahkan belum mengenal fungsi-fungsi matematik dalam Microsoft excel yang dalam menyederhanakan pekerjaannya.

Selain itu, guru belum mengenal perangkat lunak statistika seperti Minitab atau SPSS. Sebahagian pernah mendengar istilah SPSS tetapi tidak mengetahui apa dan untuk apa SPSS itu. Padahal dengan memanfaatkan perangkat lunak statistika, pekerjaan pengolahan data menjadi lebih sederhana. Kita cukup memasukkan data ke perangkat lunak, kemudian ikuti perintah yang sudah ditetapkan. Tugas kita hanyalah membaca hasil yang dikeluarkan untuk diinterpretasi sesuai permasalahan yang kita alami.

Pengolahan data rapor menggunakan microsoft excel telah dilakukan anggota tim pengabdi seperti yang dijelaskan pada [1] yang berhasil mengingkatkan kemampuan guru dalam pengolahan data rapor. Selain itu, [2] juga melakukan hal serupa dan berhasil meningkatkan kemampuan guru.

Masalah lain adalah guru mampu menyajikan data dalam bentuk tabel atau grafik sederhana, tetapi belum mampu menyajikan data dengan tabel/grafik yang memberikan informasi tentang data lebih banyak seperti diagram batang-daun atau kotak-garis. [3] menjelaskan bahwa kemampuan guru merepresentasikan kemampuan siswa. Ketidakmampuan guru pada kajian ini, akan menyebabkan siswa juga tidak mampu.

Berikutnya adalah guru bingung melakukan pengolahan data, apakah menggunakan statistika deskriptif, statistika inferensial atau statistika non parametrik. Mereka belum bisa memutuskan uji apa yang harus dilakukan terhadap data. Untuk itu, dilaksanakan kegiatan pengabdian kepada masyarakat dengan judul Pengolahan Data Menggunakan Perangkat Lunak Statistika Bagi Guru Matematika SMP Se Kabupaten 50 Kota.

\section{Solusi/Teknologi}

Upaya penyelesaian masalah yang ditemukan di lapangan, dilakukan kegiatan pengabdian masyarakat dengan judul Pengolahan Data Menggunakan Perangkat Lunak Statistika Bagi Guru Matematika SMP Se Kabupaten 50 Kota. Kegiatan ini berupa workshop/ pelatihan dan 
bersifat interaktif. Kegiatan dilaksanakan selama enam minggu pada bulan Agustus hingga September 2018.

Kabupaten 50 Kota merupakan salah satu kabupaten terluas di Sumatera Barat. Hal ini menunjukkan luasnya wilayah kerja guru yang tersebar ke seluruh penjuru daerah. Karena Kota Payakumbuh dahulunya adalah ibukota Kabupaten 50 Kota, dan akses ke Payakumbuh cukup lancar, maka kegiatan pelatihan dilaksanakan di Kota Payakumbuh, di tempat mereka biasa melaksanakan kegiatan musyawarah guru mata pelajaran.

Kegiatan pelatihan diawali dengan pembukaan yang diikuti dengan pretest untuk melihat pengetahuan guru mengenai perangkat lunak statistika dan beberapa konsep statistika sederhana. Kegiatan dilanjutkan dengan pelatihan penggunaan microsoft excel dalam pengolahan data. Pada pertemuan berikutnya diberikan pelatihan mengenai statistika deskriprif disertai praktikum. Selanjutnya pengolahan data meggunakan statistika parametrik dan praktikumnya. Pada pertemuan terakhir diberikan analisis data menggunakan statistika non parametrik, lengkap dengan praktikumnya. Kegiatan pelatihan ditutup dengan posttest, untuk melihat perubahan pengetahuan dan keterampilan guru dalam melakukan pengolahan data menggunakan perangkat lunak statistika, dalam hal ini microsoft excel, Minitab dan SPSS.

\section{Hasil dan Diskusi}

Kegiatan ini memberikan hasil berupa peningkatan pengetahuan guru mengenai pengolahan data, khususnya dengan bantuan perangkat lunak statistika. Hal ini dapat dilihat dari hasil pretest dan posttest guru.

Tabel 1. Sari Numerik Hasil Pretes Guru

\begin{tabular}{|l|c|}
\hline \multicolumn{1}{|c|}{ Statistik } & Nilai \\
\hline Banyak peserta & 33 \\
\hline Nilai minimum & 3 \\
\hline Kuartil 1 & 6 \\
\hline Median & 8 \\
\hline Kuartil 3 & 9 \\
\hline Nilai maksimum & 12 \\
\hline Rata-rata & 7.515 \\
\hline Modus & 9 \\
\hline Standar deviasi & 2.108 \\
\hline
\end{tabular}

Berdasarkan Tabel 1 dapat kita ketahui bahwa dari 15 soal yang diujikan, guru mampu menguasai secara keseluruhan sebesar 7.515. hal ini menunjukkan bahwa dari masalah yang ada, baru separoh dari guru yang terlibat yang mengetahui. Terlepas apakah guru ini menjawab berdasarkan pengetahuan atau hanya sebatas menebak. Selain itu, juga tampak bahwa lebih banyak guru yang tidak tahu dibanding dengan yang tau, yang ditunjukkan dengan selisih nilai antara median dengan Kuartil 1 lebih besar dibanding selisih median dengan Kuartil 3. Hal ini diperjelas lagi oleh selisih Kuartil 1 dan data minimum, dibandingkan selisih Kuartil 3 dan data maksimum. Selisih Kuartil 1 dan data minimum cukup besar, yang menjelaskan bahwa kemampuan/pengetahuan guru pada tingkat yang lebih rendahlah yang menonjol. Jelas bahwa kemampuan awal guru sebagaimana yang dijelaskan pada pendahuluan masih rendah/minim walaupun dengan modus 9. Namun, nilai standar deviasi 2.108 terbilang cukup besar untuk rentang nilai di atas.

Dengan dasar ini, diberikan pelatihan pengolahan data dilengkapi dengan pengetahuan statistika, ternyata diperoleh hasil yang tidak jauh berbeda, sebagaimana tertuang dari hasil posttest. Sari numerik posttest yang diberikan dapat dilihat pada Tabel 2.

Tabel 2. Sari Numerik Hasil Posttest Guru

\begin{tabular}{|l|c|}
\hline \multicolumn{1}{|c|}{ Statistik } & Nilai \\
\hline Banyak peserta & 29 \\
\hline Nilai minimum & 2 \\
\hline Kuartil 1 & 8 \\
\hline Median & 10 \\
\hline Kuartil 3 & 11.5 \\
\hline Nilai maksimum & 13 \\
\hline Rata-rata & 9.586 \\
\hline Modus & 8 \\
\hline Standar deviasi & 2.307 \\
\hline
\end{tabular}

Tabel 2 menjelaskan bahwa terjadi peningkatan rata-rata kemampuan guru dalam hal pengolahan data menggunakan perangkat lunak statistika dari 7.515 menjadi 9.586. Namun hal ini tidak sepenuhnya baik, karena standar deviasi juga meningkat menjadi 2.307. Artinya, terdapat perbedaan yang lebih besar antara kemampuan satu orang guru dengan seorang lainnya. 
Dilihat dari banyak peserta yang terlibat dalam ujian, terdapat selisih 4 orang. Hal ini terjadi karena posttest dilaksanakan pada sore hari. Ini adalah suatu masalah bagi mereka. Mengingat kondisi wilayah Kabupaten 50 yang tersebar begitu luas dan masih ada daerah yang aksesnya hanya dengan satu kendaraan dari dan ke Kota Payakumbuh dan daerah-daerah yang dimaksud memakan waktu 3 hingga 4 jam perjalanan darat. Guru-guru yang berasal dari daerah ini, meminta izin untuk meninggalkan kegiatan terlebih dahulu.

\section{Kesimpulan}

Kemampuan guru matematika dalam melakukan pengolahan data di Kabupaten 50 beragam. Diperlukan latihan dan pembiasaan dalam melakukan pemprosesan data, terutama menggunakan perangkat lunak statistika.

\section{Ucapan Terima Kasih}

Ucapan terima kasih penulis sampaikan kepada Universitas Negeri Padang yang telah membiayai kegiatan pengabdian ini dan guru matematika SMP se-Kabupaten 50 Kota sebagai mitra kegiatan.

\section{Pustaka}

[1] Dewi, M., \& Kurniawati, Y. (2018). Workshop on Using Microsoft Excel for Processing Student's Mark for Primary School's Teacher. Pelita Eksakta, 1(1), 47-49. doi :10.24036/pelitaeksakta/vol1-iss 1/14

[2] Syafriandi, S; Amalita, N; Kurniawati, Y. Upaya Peningkatan Kemampuan Analisis Data Penelitian Menggunakan Software Statistika Bagi Guru-Guru Matematika SMA Kabupaten Pesisir Selatan. Jurnal Eksakta Pendidikan (JEP). 2(1), 1-8, doi:10.24036/jep/vol2-iss1/61

[3] Syafriandi, S; Fitria, D. Analysis of Teacher's Competence About Mathematics Material for National Final Examination. Pelita Eksakta. 1(1), 20-26. doi:10.24036/pelitaeksakta/vol1 iss $1 / 5$ 